\title{
Analysis and Evaluation of Climatic Conditions Effect on Amorphous Silicon PV Module
}

\author{
B. Benabdelkrim ${ }^{1,2, *}$, T. Ghaitaoui ${ }^{3,4}$, A. Benatillah ${ }^{2}$ \\ ${ }^{1}$ Department of Material Sciences, Institute of Science and Technology, University of Ahmed Draia, Adrar, Algeria \\ ${ }^{2}$ Laboratory of Energy, Environment and Systems of Information (LEESI), University of Ahmed Draia, \\ Adrar, Algeria \\ ${ }^{3}$ Laboratoire de Développement Durable et d'information (LDDI), Faculté des Science et de la Technologie, \\ Université Ahmed Draia, Adrar, Algéria \\ ${ }^{4}$ Unité de Recherche en Energies Renouvelables en Milieu Saharien, URERMS, Centre de Développement des \\ Energies Renouvelables, CDER, 01000 Adrar, Algéria
}

(Received 07 May 2020; revised manuscript received 15 October 2020; published online 25 October 2020)

\begin{abstract}
The productivity of the PV modules installed in southern Algeria is affected by the difficult desert environmental conditions. There are several factors that must be considered in order to ensure the performance and quality of this system. Several works have been conducted in attempts to explain the real performance characterization of the a-Si PV modules when deployed outdoors. The degradation rate can be based on the comparison of the monitoring outdoor performance with the initial indoor measurements taken as references, or by applying LR (Linear Regression) and CSD (Classical Seasonal Decomposition) methods with temperature correction. The a-Si PV modules present light-induced degradation (LID) due to the StaeblerWronski effect (SWE) and are attributed to recombination-induced breaking of weak Si-Si bonds by optically excited carriers after thermalization, thus producing defects that decrease carrier lifetime. The electrical performance degradation of these modules is very important during the initial exposure to outdoor light due to changes in photoconductivity and dark conductivity. In this study, a pilot platform was created to obtain a database related to the actual environmental conditions and electrical performance parameters of the PV modules. This work assesses the impact of climatic conditions on the behavior of the QS-60DGF modules installed in the URERMS Adrar (research unit in southern Algeria). The degradation evaluation of the QS-60DGF modules was performed with various defects, using electrical properties (I-VIP-V) under daily weather conditions and visual examination (glass breaking). This study is to investigate the degradation rates of a-Si PV module after more than one year of outdoor exposure in desert conditions.
\end{abstract}

Keywords: PV modules, Electrical parameters, $I-V$ characteristic, Performance evaluation, Environmental conditions.

DOI: 10.21272/jnep.12(5).05010

PACS numbers: 61.72.uj, 61.72.Lk

\section{INTRODUCTION}

The solar energy is a free, unexploited and clean source of energy and is the focus of many recent energy researches [1-3]. The main objective of these research works is to study the factors that affect the performance of PV modules in order to look a solution for solving or limiting this effect. On the other hand, different studies in the literature compare the performance of PV modules under different operating conditions [4-6].

The manufacturers of PV modules typically give the data that are measured based on standard test conditions (STC: determined at AM 1.5 with an irradiance of $1000 \mathrm{~W} / \mathrm{m}^{2}$ and a cell temperature of $25^{\circ} \mathrm{C}$ ). Usually, these standard test conditions (STC) are not always representative of the actual operation of a PV module and the performance of these solar PV modules may decline after being exposed to outdoor field conditions due to the change in weather conditions from one environment to another and amplified by the effect of aging of the PV modules. Thus, the characterization of different types of PV modules under real-life operating conditions is essential in order to obtain a global view of the real electrical performance of different technologies at a given site.

The performance and efficiency of PV modules is influenced by several factors such as solar radiation, am- bient temperature, humidity, wind, shading and sand dust accumulation [7, 8].

The objective of this work is to conduct an empirical study on the effect of different temperatures and radiation on PV performance parameters. Performance degradation is evaluated after placing (QS-60DGF) thinfilm module in a desert environment. By using visual inspection of module defects or by the $I-V$ characteristic measurement normalized at STC condition to compare with the initial $I-V$ characteristic produced by the manufacturer (STC Nominal Data). On the other hand, an experimental investigation of the QS-60DGF module performance was carried out on two different days (clear and cloudy).

Adrar in the southern Algeria is characterized by a hot and arid climate in the summer. Hence, it is very important to understand the effect of climatic conditions of the region on PV systems in order to enable installers and investors to estimate the reliability of PV systems for a more extended lifetime. As a result, it was conducted an assessment and analysis of the degradation rate of a-Si PV module. After that, comparison of PV modules degradation from the literature by taking into account different parameters (climate, test duration) was presented.

\footnotetext{
*benaekbouchra@gmail.com
} 


\section{EXPERIMENTAL PROCEDURE AND MODULE DESCRIPTION}

Evaluation of the degradation of PV modules requires measurements of both the environmental and electrical parameters associated with the modules. As part of this work, a dedicated measurement platform has been set up operational since January 2019. It is installed on the site of Research Unit in Renewable Energies in the Saharan Medium (URERMS) in the south-west of Algeria (Adrar). It is also dedicated to determine the prevailing operating conditions of PV modules installed in our study area.

\subsection{The Measurement Site}

The measurement platform is installed in the region of Adrar located between longitude $0.27^{\circ}$ west and latitude $27.88^{\circ}$ north with an altitude of $31 \mathrm{~m}$.

Algeria has the largest solar deposit in the Mediterranean basin. The average duration of solar radiation in the Algerian territory exceeds $2000 \mathrm{~h}$ per year and can reach nearly $3500 \mathrm{~h}$ of solar radiation in the Sahara desert. The total energy received is estimated at $169400 \mathrm{TWh} /$ year, which is 5000 times higher than the annual electricity consumption of the country [9].

\subsection{Presentation of the Measurement Platform}

The measurement platform of PV module performance evaluation in this work uses the software and hardware of EKO instruments (MP-160 I-V tracer). This tracer equipment is used for the field measurement of the $I$ - $V$ characteristic curves and main characteristic parameters of solar modules. The instrument measures at the same time the voltage and current, as well as the incident solar irradiance and temperature utilizing a pyranometer and a thermocouple.

The technical specifications of the modules given by the manufacturer are shown in Table 1.

Table 1 - STC specifications for the three modules

\begin{tabular}{|l|c|c|}
\hline Parameters & Symbol & a-Si TF (QS-60DGF) \\
\hline Maximum power & $P_{m}(\mathrm{~W})$ & 60 \\
\hline Open-circuit voltage & $V_{o c}(\mathrm{~V})$ & 80.3 \\
\hline Short-circuit current & $I_{s c}(\mathrm{~A})$ & 1.22 \\
\hline Voltage at maximum power & $V_{m p}(\mathrm{~V})$ & 62.3 \\
\hline Current at maximum power & $I_{m p}(\mathrm{~A})$ & 0.96 \\
\hline Temperature coefficient of open-circuit voltage & $K_{v}(\% / \mathrm{K})$ & -0.28 \\
\hline Temperature coefficient of short-circuit current & $K_{i}(\% / \mathrm{K})$ & 0.09 \\
\hline
\end{tabular}

\section{EXPERIMENTAL RESULTS AND DISCUSSION}

\subsection{Degradation Analysis Methodology}

There are several methods to assess the PV modules degradation such as visual inspection, $I-V$ characteristic measurement normalized at STC condition, and analytical calculation of the degradation rates $[10,11]$.

In this work, the investigation of QS-60DGF module was carried out using visual inspection, outdoor $I-V$ and $P-V$ characteristic measurements of the module under STC.

\subsubsection{I-V and $P-V$ Characteristic Curves}

\section{Measurement Results}

Before treating degradation of electrical performance, it is advisable to analyze climate data. Measurements were carried out at Adrar in the southern Algeria. Fig. 1-Fig. 3 provide a summary of climate data for both clear and cloudy days. All data values were measured every $15 \mathrm{~min}$ from 12:00 a.m. to 11:45 p.m.

Fig. 4 presents the results of the experimental investigation of both clear and cloudy days (clear day: 13-032019 at 11:25 a.m., cloudy day: 04-04-2019 at 11:04 a.m.). The electrical parameters of these dusty and clean modules are provided in Table 2 in order to assess the effect of a cloudy day and the dust on the output power reduction with increasing solar irradiance. Both the open-circuit voltage and short-circuit current increase and hence the maximum power point varies.
We note that the output power difference between the clean module in a clear day and the clean module in a cloudy day is equal to $42.7 \mathrm{~W}$, and the output power difference between the clean module and the dusty module in a cloudy day is equal to $2.77 \mathrm{~W}$. The cause of this variation is the reduction in intensity of sunlight reaching the PV module, leading to the decrease in the shortcircuit current ( $I_{s c}$ of a clean module in a cloudy day is $0.25 \mathrm{~A}, I_{s c}$ of a clean module in a clear day is $1.21 \mathrm{~A}$ ).

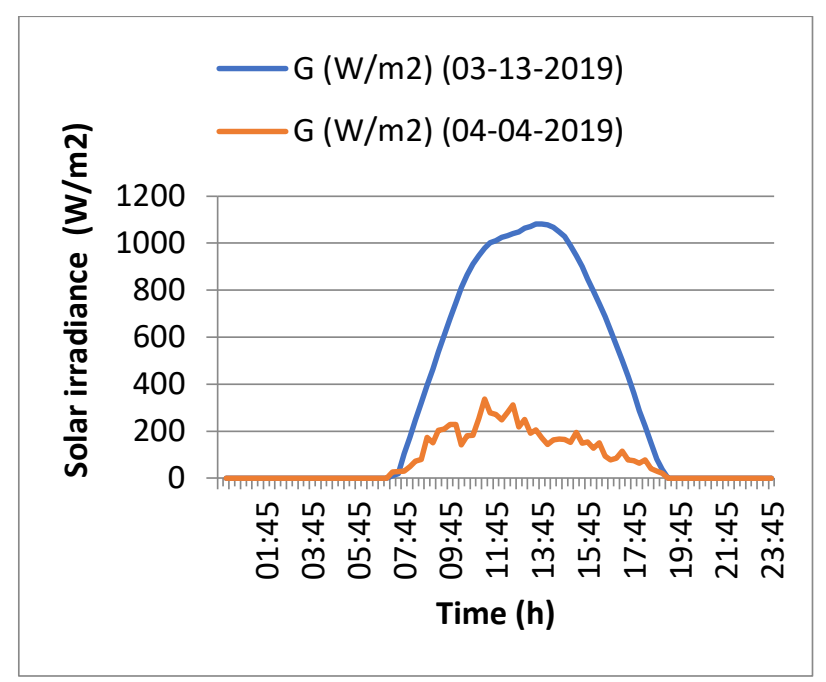

Fig. 1 - Solar irradiance of both clear (13-03-2019) and cloudy (04-04-2019) days 

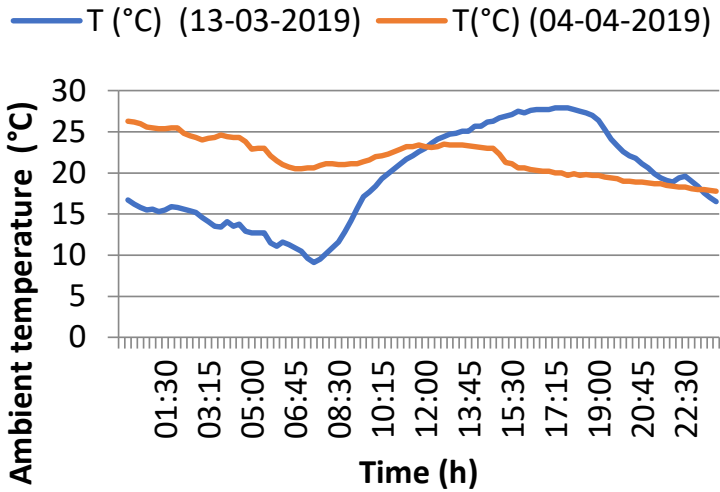

Fig. 2 - Ambient temperature of both clear (13-03-2019) and cloudy (04-04-2019) days

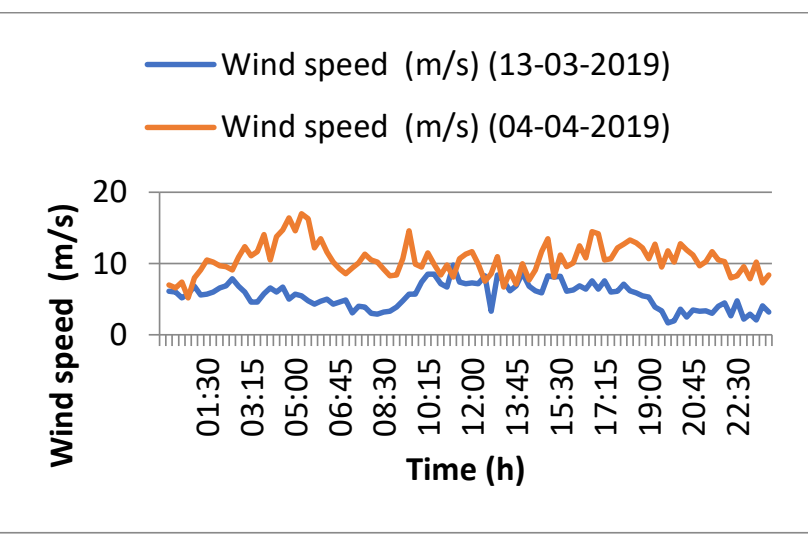

Fig. 3 - Wind speed of both clear (13-03-2019) and cloudy (0404-2019) days
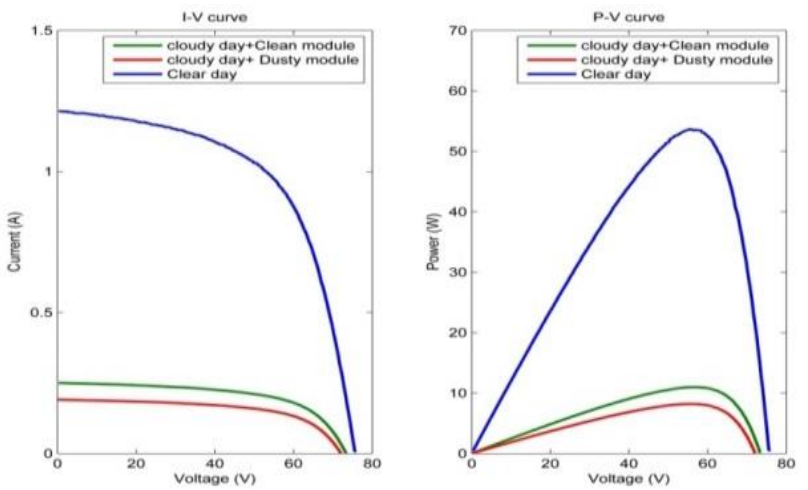

Fig. $4-I-V$ and $P$ - $V$ curves of dusty and clean modules under operating climatic conditions

\subsubsection{Visual Inspection Results}

Glass breakage is an important degradation factor in PV modules. This occurs most often during installation and maintenance, especially during the transfer of PV modules on their installation sites.

From Table 3, a loss of more than $35 \%$ of output power is observed on this test. Glass breakage is an event that can be attributed to thermal stress.

Based on the experimental results, a cracked PV module is practically diagnosed by the $I-V$ and $P-V$ characteristics, which present a significant drop of $I_{\mathrm{sc}}$
(Fig. 5). There is also a drop of the resultant $P_{\max }$ and fill factor $(\mathrm{FF})$. However, the open-circuit voltage $\left(V_{o c}\right)$ has a lower degradation.
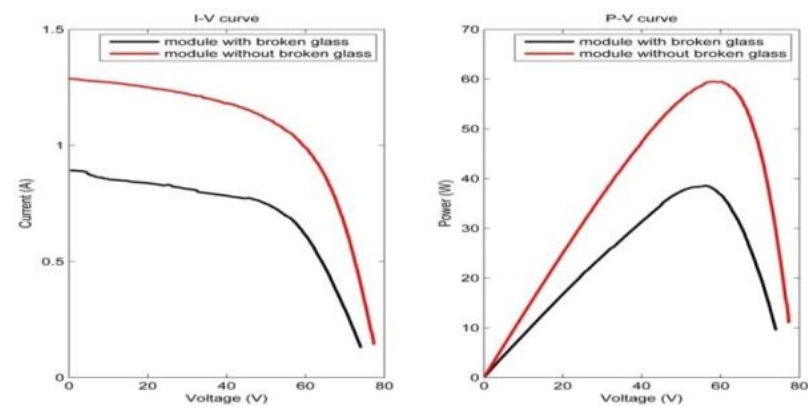

Fig. 5 - The $I-V$ and $P$ - $V$ characteristics results

\section{Rates \\ 3.1.3 Analytical Calculations of Degradation}

To assess the PV modules performance, the degradation rate $\left(R_{D}\right)$ of each parameter was determined under real climatic conditions by the following analytical expression [12]:

$$
R_{D}(X)(\%)=\left(1-\frac{X}{X_{0}}\right) \times 100,
$$

where $X$ is the maximum output current $\left(I_{\max }\right)$, maximum output voltage $\left(V_{\max }\right)$, maximum power output $\left(P_{\max }\right)$, open-circuit voltage $\left(V_{o c}\right)$, short-circuit current $\left(I_{s c}\right)$ and fill factor $(\mathrm{FF})$ after degradation and $X_{0}$ represents the reference (nominal) values of the parameters given by the manufacturer data under STC $\left(P_{\max 0}, I_{\max 0}\right.$, $\left.V_{\max 0}, I_{s c 0}, V_{o c 0}, \mathrm{FF}_{0}\right)$.

The annual degradation rate $\left(R_{D a}\right)$ is calculated from the global degradation factor. In this equation, $\Delta t$ represents the module's exposure period (in years) from the first operation day until the test date:

$$
R_{D a}(X)(\%)=\frac{G_{D}}{\Delta t} .
$$

Table 4 contains the values of degradation rate $\left(R_{D}\right)$ and annual degradation rate $\left(R_{D a}\right)$ for each performance parameter of PV modules with broken glass after 14 months of outdoor exposure in real conditions.

Based on the experimental results, a cracked PV module is practically diagnosed by an $I-V$ characteristic which presents a significant drop of $I_{s c}$ (Fig. 7). There is also a drop of the resultant $P_{\max }$ and FF. However, the open-circuit voltage $\left(V_{o c}\right)$ has a lower degradation rate.

In order to compare the $R_{D a}$ values found for $P_{m}$ in our climate with other climates, we summarized in Table 5 different values found in the literature.

By means of comparison, studies conducted on outdoor exposed a-Si PV modules exhibited approximately 1.76-2.21\%/year performance loss [15]. However, it has been reported that $R_{D a}$ values are of $20.4 \%$ in Malaysia and $18.8 \%$ in Australia and Spain.

These values are lower than what we found in our measurement, this is mainly due to the harsh atmosphere in our region. 
Table 2 - Parameters of clean and dusty PV modules

\begin{tabular}{|l|c|c|c|c|c|c|c|}
\hline Parameters & $\boldsymbol{I}_{\boldsymbol{s c}}[\mathrm{A}]$ & $\boldsymbol{V}_{\boldsymbol{o c}}[\mathrm{V}]$ & $\boldsymbol{I}_{\boldsymbol{p m}}[\mathrm{A}]$ & $\boldsymbol{V}_{\boldsymbol{p m}}[\mathrm{V}]$ & $\boldsymbol{P}_{\boldsymbol{m}}[\mathrm{W}]$ & $\mathbf{F F}$ & $\eta[\%]$ \\
\hline Clear day + clean module & 1.21 & 75.67 & 0.97 & 55.43 & 53.66 & 0.58 & 4.90 \\
\hline Cloudy day+ clean module & 0.25 & 73.39 & 0.19 & 56.57 & 10.96 & 0.59 & 4.59 \\
\hline Cloudy day+ dusty module & 0.19 & 72.1 & 0.15 & 56.09 & 8.19 & 0.59 & 4.35 \\
\hline
\end{tabular}

Table 3 - Parameters for PV modules with and without broken glass

\begin{tabular}{|l|c|c|c|c|c|c|c|}
\hline Parameters & $\boldsymbol{I}_{\boldsymbol{s c}}[\mathrm{A}]$ & $\boldsymbol{V}_{\boldsymbol{~ o c ~}}[\mathrm{V}]$ & $\boldsymbol{I}_{\boldsymbol{p m}}[\mathbf{A}]$ & $\boldsymbol{V}_{\boldsymbol{p m}}[\mathrm{V}]$ & $\boldsymbol{P}_{\boldsymbol{m}}[\mathrm{W}]$ & $\mathbf{F F}$ & $\boldsymbol{\eta}[\%]$ \\
\hline Unbroken module & 1.29 & 79.21 & 1.02 & 58.45 & 59.51 & 0.58 & 5.34 \\
\hline Broken module & 0.90 & 77.19 & 0.69 & 56.29 & 38.58 & 0.55 & 3.46 \\
\hline
\end{tabular}

Table 4 - Degradation parameters of broken PV modules under STC conditions

\begin{tabular}{|l|l|l|l|l|l|l|}
\hline Parameters & $\boldsymbol{I}_{\boldsymbol{s c}}[\mathbf{A}]$ & $\boldsymbol{V}_{\boldsymbol{o c}}[\mathrm{V}]$ & $\boldsymbol{I}_{\boldsymbol{p} m}[\mathrm{~A}]$ & $\boldsymbol{V}_{\boldsymbol{p m}}[\mathrm{V}]$ & $\boldsymbol{P}_{\boldsymbol{m}}[\mathrm{W}]$ & $\mathbf{F F}$ \\
\hline $\boldsymbol{R}_{\boldsymbol{D}}(\%)$ & 26.23 & 3.87 & 28.12 & 9.65 & 35.7 & 14.06 \\
$\boldsymbol{R}_{\boldsymbol{D a}}(\% /$ years $)$ & 21.85 & 3.22 & 23.43 & 8.04 & 29.75 & 11.71 \\
\hline
\end{tabular}

Table 5 - Summary of some studies on thin-film PV module field degradation around the world

\begin{tabular}{|c|c|c|c|c|c|}
\hline Location & Climate & Test duration & $\begin{array}{c}\text { Modules } \\
\text { technology }\end{array}$ & $\begin{array}{c}\text { Degradation rate } \\
(\% / \text { years })\end{array}$ & Reference \\
\hline $\begin{array}{l}\text { Perth } \\
\text { (Australia) }\end{array}$ & Temperate & 16-19 months & $\begin{array}{l}\text { a-Si } \\
\text { CIS }\end{array}$ & $\begin{array}{l}18.8 \\
12.6\end{array}$ & [13] \\
\hline $\begin{array}{l}\text { Mesa, Arizona } \\
\text { (USA) }\end{array}$ & Desert & $\begin{array}{l}2.7 \text { years } \\
6.7 \text { years }\end{array}$ & $\begin{array}{l}\mathrm{a}-\mathrm{Si} \\
\mathrm{a}-\mathrm{Si}\end{array}$ & $\begin{array}{l}3.52 \\
1.16\end{array}$ & {$[14]$} \\
\hline $\begin{array}{l}\text { Cologne } \\
\text { (Germany) }\end{array}$ & Sub-oceanic & 5 years & $\begin{array}{l}\text { a-Si (A) } \\
\text { a-Si (B) }\end{array}$ & $\begin{array}{l}1.76 \\
2.21\end{array}$ & [15] \\
\hline $\begin{array}{l}\text { Benguerir } \\
\text { (Morocco) }\end{array}$ & Desert & 2.5 years & $\mathrm{TF}$ & 1.73 & {$[16]$} \\
\hline Malaysia & Humid climatic & 16 months & a-Si & 20.4 & [17] \\
\hline $\begin{array}{l}\text { Gurgaon, } \\
\text { India }\end{array}$ & Sub-tropical & 28 months & $\mathrm{a}-\mathrm{Si}$ & 6.4 & [18] \\
\hline Jaén (Spain) & Dry and sunny & 16 months & $\mathrm{a}-\mathrm{Si}$ & 18.8 & [19] \\
\hline Present study & Desert & 14 months & $\mathrm{a}-\mathrm{Si}$ & 29.7 & \\
\hline
\end{tabular}

Another important remark from the previous studies is that the degradation process goes through two different stages: a rapid degradation for the first years of exposure followed by a slow linear degradation rate [20].

\section{CONCLUSIONS}

Our work is part of a process of analyzing failure modes of PV systems installed in the south of Algeria. The exploitation of characteristics $(I-V)$ of QS-60DGF module allowed us to make the comparison between different situations typical to a Saharan environment.

The results of cloudy day effect show that the output power production of the tested module was decreased from $53.66 \mathrm{~W}$ (clear day and clean module) to $10.96 \mathrm{~W}$ (cloudy day and clean module).

The obtained experimental results show that the loss of the maximum output power $\left(P_{\max }\right)$ of a module without glass breakage is $59.51 \mathrm{~W}$ and of a module with glass breakage is $38.58 \mathrm{~W}$ which prove the effect of long time exposure of modules under desert climatic conditions.

The average degradation rate, however, is around $29 \% / y e a r$. This value is relatively higher than what we found in literature. This is mainly due to the harsh atmosphere in Adrar, southern Algeria. Nevertheless, this region has one of the best solar potential in the world with $3500 \mathrm{~h}$ of solar radiation per year.

In future works, we will study the major causes and factors of degradations noted in this paper. It is necessary to increase the number of modules studied over longer exposure duration in our study area.

\section{ACKNOWLEDGEMENTS}

The authors would like to acknowledge the support provided by the Research Unit in Renewable Energies in the Saharan Medium (URERMS), Adrar, Algeria for providing the necessary facilities to carry out this work and particularly thank Mr. Othmani Mourad. 


\section{REFERENCES}

1. T. Ghaitaoui, A. Benatiallah, H. Khachab, K. Koussa, J. Ovonic Res. 14 No 2, 79 (2018).

2. G. Oreski, G.M. Wallner, Sol. Energy. 79, 612 (2005).

3. Touhami Ghaitaoui, Ali Benatiallah, Youcef Sahli, Hamid Khachab, J. Nano- Electron. Phys. 10 No 1, 01008 (2018).

4. B. Benabdelkrim, A. Benatillah, Smart Energy Empowerment in Smart and Resilient Cities: Lecture Notes in Networks and Systems (Ed. M. Hatti) 102, 641 (Springer: Cham: 2020).

5. R. Siddiqui, R. Kumar, G.K. Jha, G. Gowri, M. Morampudi, P. Rajput, S. Lata, S. Agariya, B. Dubey, G. Nanda, Energy 107, 550 (2016).

6. B. Benabdelkrim, A. Benatillah, International Journal of Energetica (IJECA) 2 No 2, 06 (2017).

7. Dirnberger Daniela, Blackburn Gina, Müller Björn, Reise Christian, Sol. Energy Mater. Sol. Cells. 132, 431 (2015).

8. B. Benabdelkrim, A. Benatillah, T. Ghaitaoui, J. Nano- Electron. Phys. 11 No 5, 05008 (2019).

9. Site société de SKTM. http://www.sktm.dz/?page=article\&id=11.

10. S.S. Chandel, M. NagarajuNaik, Sharma Vikrant, Chandel Rahul, Renew. Energ. 78, 193 (2015).
11. C. Jordan Dirk, B. Sekulic, B. Marion, R. Kurtz Sarah, IEEE J. Photovoltaics 5 No 3, 744 (2015).

12. J.A. Tsanakas, L. Ha, C. Buerhop, Renew Sustain Energy Rev, 62, 695 (2016)

13. A.J. Carr AJ, T.L. Pryor, Sol. Energy 76, 285 (2004).

14. B. Raghuraman, V. Laksman, J. Kuitche, W. Shisler, G. Tamizhani, H. Kapoor, 4th IEEE World Conference on Photovoltaic Energy Conversion (Hawaii: USA: 2006).

15. I. Faye, A. Ndiaye, D. Kobor, U. Blieske, M. Ayituv, Afr. J. Env. Sci. Technol. 12 No 12, 461 (2018).

16. A. Bouaichi, A. Alami Merrouni, C. Hajjaj, H. Zitouni, A. Ghennioui, A. El Amrani, C. Messaoudi, Energy Procedia 157, 1210 (2019).

17. M. Hussin, S. Shaari, A. Omar, Z. Zain, Renew. Sustain. Energy Rev. 43, 388 (2015).

18. V Sharma, O.S. Sastry, A. Kumar, B. Bora, S.S. Chandel, Energy 72, 536 (2014).

19. S. Kichou, S. Silvestre, G. Nofuentes, M. Torres-Ramírez, A. Chouder, D. Guasch, Energy 96, 231 (2016).

20. C.R. Osterwald, J.P. Benner, J. Pruett, A. Anderberg, S. Rummeland, L. Ottoson, 3rd World Conference on Photovoltaic Energy Conversion, 2911 (Osaka: Japan: 2003).

\title{
Аналіз та оцінка впливу кліматичних умов на фотоелектричний модуль з аморфного кремнію
}

\author{
B. Benabdelkrim ${ }^{1,2}$, T. Ghaitaoui ${ }^{3}$, A. Benatillah ${ }^{2}$
}

${ }^{1}$ Department of Material Sciences, Institute of Science and Technology, University of Ahmed Draia, Adrar, Algeria

${ }^{2}$ Laboratory of Energy, Environment and Systems of Information (LEESI), University of Ahmed Draia, Adrar, Algeria

${ }^{3}$ Laboratoire de Développement Durable et d'information (LDDI), Faculté des Science et de la Technologie, Université Ahmed Draia, Adrar, Algéria

4 Unité de Recherche en Energies Renouvelables en Milieu Saharien, URERMS, Centre de Développement des Energies Renouvelables, CDER, 01000 Adrar, Algéria

На продуктивність фотоелектричних (PV) модулів, встановлених на півдні Алжиру, впливають складні умови пустелі. Існуе кілька факторів, які необхідно враховувати, щоб забезпечити їх роботу та якість. Було проведено декілька робіт у спробах пояснити реальну продуктивності PV-модулів a-Si при розміщенні на відкритому повітрі. Швидкість деградації може базуватися на порівнянні результатів моніторингу продуктивності на відкритому повітрі з початковими вимірюваннями в приміщенні, взятих як еталон, або на застосуванні методів LR (лінійна регресія) та CSD (класичне сезонне розкладання) $з$ корекціею температури. PV-модулі а-Si демонструють індуковану світлом деградацію внаслідок ефекту Стаблера-Вронського і пов'язані з індукованим рекомбінацією розривом слабких зв'язків $\mathrm{Si}-\mathrm{Si}$ оптично збудженими носіями після термалізації, створюючи, таким чином, дефекти, що зменшують час життя носія. Деградація електричних характеристик таких модулів дуже важлива під час первинного впливу зовнішнього світла через зміни фотопровідності та темнової провідності. У роботі була створена пілотна платформа для отримання бази даних, що стосується фактичних умов навколишнього середовища та параметрів електричних характеристик PV-модулів. Проведено оцінювання впливу кліматичних умов на поведінку модулів QS-60DGF, встановлених в URERMS Adrar (дослідницька установа на півдні Алжиру). Оцінку деградації модулів QS-60DGF проводили з різними дефектами, використовуючи електричні властивості (I-V/P-V) в повсякденних погодних умовах та візуальне обстеження. Дослідження призначене для вивчення швидкості деградації PV-модуля a-Si після більш ніж одного року перебування на відкритому повітрі в умовах пустелі.

Ключові слова: Фотоелектричні (PV) модулі, Електричні параметри, ВАХ-характеристика, Оцінка продуктивності, Умови навколишнього середовища. 